\title{
Effect of crop rotations of rain-fed and irrigated autumn-sown and spring-sown forage on milk feed unit and soil traits in the European Mediterranean environment
}

\author{
Pasquale Martiniello, ${ }^{1}$ Salvatore Claps ${ }^{2}$ \\ ${ }^{1}$ Agricultural Research Council, Extensive Animal Production Unit, Experimental farm \\ (former Institute for Livestock Division), Foggia; ${ }^{2}$ Agricultural Research Council, Extensive \\ Animal Production Unit, Muro Lucano (PZ), Italy
}

\begin{abstract}
The aim of this study is to assess the agronomic effect of a threeyear continuous intensive double-crop cultivation of different varieties of legumes and grasses sown in autumn and grasses sown in spring under irrigated and rain-fed conditions in the European Union (EU) Mediterranean environment. Our experiment aimed to compare the dry matter (DM, t ha ${ }^{-1}$ ) and the milk feed unit (MFU, $\mathrm{kg}(\mathrm{DM})^{-1}$ ) from silage production and soil characteristics of popular autumn-sown Italian ryegrass (Lolium multiflorum Lam.) and spring-sown maize (Zea mays L.) compared with other crop system legume and grass varieties. The autumn and spring legume and grass varieties were grown under either rain-fed or irrigated conditions. The investigated traits, i.e. DM, MFU and organic carbon ( $\left.\mathrm{OC}, \mathrm{g} \mathrm{kg}^{-1}\right)$, were influenced by the cropping system, the sowing time and the irrigation treatments. The mean total number of MFU ha ${ }^{-1}$, derived from the potential silage yield of legume and grass autumn varieties, ranged from 4297 to $5895 \mathrm{MFU}$ $\mathrm{ha}^{-1}$ under rain-fed conditions and from 5778 to $7871 \mathrm{MFU} \mathrm{ha}^{-1}$ with
\end{abstract}

Correspondence: Pasquale Martiniello, CRA-ZOE Istituto per la Zootecnia, S.S. per Napoli Km 12, 71100 Foggia, Italy.

Tel.Fax: +39.0825.475356.

E-mail: pasquale-martiniello@alice.it

Key words: autumn legume and grass sown varieties, dry matter silage production, fodder cropping system, intensive double year crop systems, milk feed unit, rain-fed-irrigated treatments and topsoil characteristics.

Acknowledgments: this research was part of the Italian project entitled Development of forage and animal husbandry cropping system models in Mediterranean environments for specific quality of the livestock gross products funded by the Italian Ministry for Agriculture, Food and Forestry. The authors are thankful to the English teacher Mrs. Antonella D'Amato for her suggestions and comments during the preparation of the manuscript.

Received for publication: 20 February 2014.

Revision received: 18 June 2014.

Accepted for publication: 18 June 2014.

(C) Copyright P. Martiniello and S. Claps, 2014

Licensee PAGEPress, Italy

Italian Journal of Agronomy 2014; 9:594

doi:10.4081/ija.2014.594

This article is distributed under the terms of the Creative Commons Attribution Noncommercial License (by-nc 3.0) which permits any noncommercial use, distribution, and reproduction in any medium, provided the original author(s) and source are credited. irrigation, respectively. The MFU ha- ${ }^{-1}$ observed in varieties sown in spring under rain-fed conditions was 8926 for grain sorghum (Sorghum bicolor L. (Moench)), 12,459 for silage sorghum; and 15,148, 24,004, 20,323 and 13,521 for lucerne (Medicago sativa L.), maize, silage and grain sorghum grown with irrigation respectively. Furthermore, the mean MFU ha ${ }^{-1}$ of autumn and spring legume and grass varieties used for grain consumption, in comparison to those of silage, was reduced by $67.6 \%$ under rain-fed conditions and $53.4 \%$ with irrigation. Three years of continuous rotations of irrigated autumn and spring grass varieties reduced the initial experimental content of OC by $2.49 \mathrm{~g} \mathrm{~kg}^{-1}$ in the autumn grass and $1.50 \mathrm{~g} \mathrm{~kg}^{-1}$ in legumes, while under rain-fed conditions the decrease was $0.81 \mathrm{~g} \mathrm{~kg}^{-1}$ and $1.86 \mathrm{~g} \mathrm{~kg}^{-1}$ in autumn legumes and grass respectively.

\section{Introduction}

The weather conditions of the European Union (EU) Mediterranean environment favour the cultivation of fodder crops with a SeptemberJune vegetative cycle. In these environments, during our study, total rainfall in the September-June period was $80 \%$ of the total yearly amount and mean temperature was under $25^{\circ} \mathrm{C}$, while solar radiation and evapotranspiration (ETo) were $49.0 \%$ lower than those of other months.

The exploitation of natural resources by intensive double-cropping cultivation per year in the utilised agricultural area (UAA) of the EU during the hot and dry June-September seasons is conducted by adopting appropriate agronomic management techniques.

In the EU lands, the success of spring cultivations under irrigated conditions depends on the availability of water in the farms that can sustain crop development in the summer period. By contrast the success of rain-fed cultivations relies significantly on the availability of adapted varieties that can withstand the critical phase of plant development during harsh weather conditions (Le Gal et al., 2010; ÁlvaroFuentes et al., 2011; Groot and Rossing, 2011; Martiniello, 2011). There is a greater availability of seeds of forage crop varieties adapted to autumn and spring sowing for irrigated cultivation compared with those for rain-fed cultivation. Given the large availability of Italian ryegrass and maize varieties on the seed market in developed countries, they are widely cultivated in UAA lands of the EU (Martiniello et al., 2007). Besides the widespread availability of these seeds on the market, the cropping systems based on the Italian ryegrass and maize varieties offer more agronomic benefits (availability of adapted edaphic varieties), technical advantages (mechanical equipment for crop growing and silage making) and savings [cheapest milk feed unit (MFU)] than the cultivation of other cropping systems with other forage crop varieties (Martiniello et al., 2007). However, the long-term 
cultivation of Italian ryegrass-maize cropping system significantly affects the soil fertility parameters (Martiniello et al., 2007). Therefore the adoption of incorrect management practices in the cropping system (e.g. long-term continuous crop rotation) has negative implications on the organic carbon (OC) of the soil (Le Gal et al., 2010; Álvaro-Fuentes et al., 2011; Le Groot et al., 2011; Martiniello, 2011). However, in the EU Mediterranean environments, limited information is available on correct agronomic management techniques to exploit natural resources in intensive double-cropping systems under rain-fed and irrigated conditions. Therefore studies aimed to enhance agronomic knowledge on intensive double forage crops per year under irrigated and rain-fed conditions are highly valuable from the ecological point of view, as they may help reduce the impact of weather conditions on fodder crop production and topsoil characteristics (Martiniello et al., 2007; Le Gal et al., 2010).

The aim of our experiment was to compare the agronomic effect of autumn-spring forage, legume and grass varieties over a three-year continuous crop rotation under rain-fed and irrigated conditions of Mediterranean UAA, dry matter (DM) and seed yield (SY, t ha ${ }^{-1}$ ), MFU and chemical characteristics of the topsoil Ap horizon.

\section{Materials and methods}

\section{Field experiments}

The experiment was conducted at A. Minichella's farm, an agricultural research centre located in Foggia ( $\left.41^{\circ} 31^{\prime} \mathrm{N} ; 1^{\circ} 33^{\prime} \mathrm{E}\right)$ between 2006 and 2008. The soil was a Chromic Vertisoil (FAO-ISRIC-ISSS, 1998) with a De Martonne's aridity index around 15. The soil properties of the 0-35 cm Ap horizon, prior to the beginning of the experiment, were as follows: sand $(2-0.2 \mathrm{~mm}) 200 \mathrm{~g} \mathrm{~kg}^{-1}$; fine sand $(0.2-0.02 \mathrm{~mm}) 350 \mathrm{~g} \mathrm{~kg}^{-1}$; silt $(0.02-$ $0.002 \mathrm{~mm}) 190 \mathrm{~g} \mathrm{~kg}^{-1}$, clay $(<0.002 \mathrm{~mm}) 260 \mathrm{~g} \mathrm{~kg}^{-1}$; total nitrogen $(\mathrm{N})$, $1.43 \mathrm{~g}, \mathrm{~kg}^{-1}$ (Kjeldahl, 1983); OC $14.6 \mathrm{~g} \mathrm{~kg}^{-1}$ (Walkley and Black, 1934); carbon nitrogen ratio (C/N) 9.8; phosphorus (P), $26 \mathrm{mg} \mathrm{kg}^{-1}$ (Olsen et al., 1954); potassium (K), $1388 \mathrm{mg} \mathrm{kg}^{-1}$ (UNICHIM, 1985); and $\mathrm{pH}$ (water) 8.1.

Figure 1 reports the monthly mean weather parameters, such as rainfall, temperature, ETo, recorded by a Class A water pan evaporimeter, and global solar radiation assessed by a radiometer for each year of the study.

At the beginning of the experiment, the field was cultivated by a rotation scheme including two years of durum wheat (Triticum durum Desf.) followed by one year of an annual mixture of oats (Avena sativa L.) and common vetch (Vicia sativa L.) with a seed density rate of 120 and $60 \mathrm{~kg} \mathrm{ha}^{-1}$ respectively.

In the $3^{\text {rd }}$ week of September of the experimental years $(2005,2006$ and 2007), a $35 \mathrm{~cm}$-deep Ap horizon soil layer cultivated with an annual mixture of grass-legume meadow was ploughed to prepare the seedbed to sow the autumn varieties of the crop systems. The ploughed soil was fertilised and a week later smoothed with a field cultivator and a tine harrow (Table 1).

To determine the effect of the three-year continuous rotation of agronomic treatments (crop systems, irrigations and sowing time) on the biomass and the biochemical characteristics of the topsoil, the same varieties were used in the crop systems throughout the entire period. However, the term silage adopted in this paper is a potential destination of DM yield of the forage crop varieties used in the cropping system models. The autumn and spring varieties in the crop systems for the various years were randomly established at the beginning of the experiment, while the experimental design remained unchanged throughout the entire period.
The field experiment was conducted in plots of $120 \mathrm{~m}^{2}(6 \mathrm{~m}$-wide and $20 \mathrm{~m}$-long) with irrigation and $48 \mathrm{~m}^{2}$ (6 m-wide and $8 \mathrm{~m}$-long) under rain-fed conditions. The total number of plots of autumn and spring crop systems was 32 with irrigation and 32 under rain-fed treatment arranged in a split-plot design with irrigation as main plot and the cropping system as subplot.

Each crop system included two varieties sown in autumn and spring treated with irrigation and under rain-fed conditions. The forage crop system based on varieties sown in autumn and spring under both treatments was named forage crop model. There were four forage crop systems, which are indicated in figures, tables and text as model I, model II, model III and model IV. Table 2 reports legume and grass species and variety names, seed rates, seedling growth, fertilisers, silage and seed harvests used in the crop models. The autumn and spring varieties of the models were included in a randomised block design and replicated four times in the subplots. The autumn varieties treated with irrigation and under rain-fed conditions were: barley (Hordeum vulgare L.), Italian ryegrass, lucerne and squarrose clover (Trifolium squarrosum L.), broad bean (Vicia faba L.) and pea (Pisum sativa L.). The spring species used in the crop models were lucerne, maize and grain sorghum. Maize and sorghum were planted by overseeding the varieties (40 and $15 \mathrm{~kg} \mathrm{ha}^{-1}$ respectively) in rows. When the seedlings had completed the development of two fully expanded leaves, the plots under rain-fed and irrigated conditions were thinned at the experimental plant density reported in Table 2 . All varieties sown in autumn and spring were planted using a seed drill machine with equally-spaced boring tools. The times of application of the agronomic management practices to the cropping system during plant development and harvest are shown in Table 1.

The DM and SY of autumn-sown varieties (barley, broad bean and pea) and spring-sown varieties (maize and sorghum) were evaluated by splitting the plot into two equal parts. One was used to calculate the SY and the other the DM. Because Italian ryegrass, sorghum silage and squarrose clover were fodder crops, used only for DM production, the data regarding SY are not reported in tables and figures.

Annual fodder grass varieties were fertilised during the seedbed preparation with a nitrogen and phosphorous binary fertiliser (as ammonium phosphate), while annual and perennial legumes were fertilised only with a phosphorous fertiliser (as double phosphate). In February, when the annual grass varieties reached the beginning of heading, another nitrogen fertiliser (as urea) was topdressed, while the two- and three-year-old lucerne meadow was topdressed with phosphorous. The amount and time of fertiliser applications to crops under rain-fed and irrigated treatment in the various years are reported in Tables 1 and 2, respectively.

The gross crop yield was assessed on the plot harvest using experimental machinery. Before crop harvest, two samples of the above ground biomass were picked up from a $0.5 \mathrm{~m}$ section of a row to determine moisture at harvest, yield component traits [stems $\mathrm{m}^{-2}$, fructiferous organs stem ${ }^{-1}$, seed per fructiferous organs and harvest index (HI, ratio of seed yield and biomass weight express in percentage)] and to make the chemical tests to assess the qualitative parameters for MFU determination.

After harvesting the autumn varieties, the plots were ploughed, fertilised with nitrogen and phosphorous and tinned with a cultivator and a harrow for the preparation of the seedbed for the spring-sown varieties of maize and sorghum. When the maize and sorghum plants of plots under rain-fed and irrigated treatments developed their $4^{\text {th }}$ fullyexpanded leaves from those of the whorl, they were topdressed fertilised. The amount and formula of the fertiliser and the time of application are reported in Tables 1 and 2, respectively.

In all agronomic treatments of the experiment, weeding was made by hand, when necessary. The rain-fed spring-sown varieties were not 
irrigated after planting, while for the irrigated varieties water irrigation was scheduled on the basis of ETo according to Doorenbos and Kassam method (1979). During the vegetative cycle, the autumn varieties were irrigated once, while some varieties sown in spring, such as maize, lucerne and sorghum, were irrigated eight and five times respectively.

The varieties were irrigated when the crop ETo calculated by Doorenbos and Kassam method (1979) reached $80 \mathrm{~mm}$. Irrigation of autumn and spring crops was made with a 16 m-long horizontal bar above the soil surface by applying a fixed water volume $\left(500 \mathrm{~m}^{3} \mathrm{ha}^{-1}\right)$. The nozzle pressure was $0.19 \mathrm{MPa}$ and the equipment was moved by a hydraulic system.

The biomass of the varieties used for DM and SY were harvest when the plant had reached a $70-75 \%$ and $12-13 \%$ moisture content, respectively.

The following traits of the plot were assessed: plant height, DM and SY. Before the harvest, the plant height $(\mathrm{cm})$ was determined by measuring at random six plants from ground level to the apex of the main tillers. The DM of the forage biomass and the SY at harvest were determined on fresh herbage from each experimental plot. The moisture determination of herbage and seed content at harvest were assessed from a sample of about $500 \mathrm{~g}$ of harvested product, dried at $65^{\circ} \mathrm{C}$ with forced air ventilation for $72 \mathrm{~h}$ and then weighted. Stem density (tiller or plant $\mathrm{m}^{-2}$ ) was determined on samples picked up from two $0.5 \mathrm{~m} \mathrm{sec}$ tions of rows manually moved prior to harvest the plot.

\section{Laboratory qualitative seed and biomass characteristics}

The chemical parameters were assessed on the biomass samples taken from two $0.5 \mathrm{~m}$ sections of the rows. After harvesting, a sample of about $1000 \mathrm{~g}$ of kernels and stem biomass was air-dried at $65^{\circ} \mathrm{C}$ until the DM reached a constant weight, in a chamber with forced ventilation, and then ground with a Cyclotec mill with a 1-mm diameter mesh screen. The samples were hermetically sealed and stored in a cool room at a temperature of $4^{\circ} \mathrm{C}$ until the chemical analyses were made. The quality traits analysed were crude protein (Kirsten, 1983), crude fibre, neutral and acid detergent fibres and acid detergent lignin (Goering and van Soest, 1970). All tests were conducted twice. The data of the stem and seed analyses were used for the MFU determination according to Demarquilly procedure (1980). The formula adopted for the MFU (well-known with the name of INRA) is based on the following traits: crude protein, crude and lignin fibres. Furthermore, the forage quality characteristics assessed by the INRA equation is largely used in most livestock laboratories for animal feeding of the European countries. The number of MFU per hectare (MFU ha-1) of each crop was calculated by multiplying the value of MFU, the DM of silage or the SY by 10,000 . The total number of MFU ha ${ }^{-1}$ of each crop system was calculated by summing up the MFU ha $^{-1}$ of the autumn and spring varieties models. According to the possible uses of forage fodder crops, three kinds of MFU ha ${ }^{-1}$ were considered: silage-silage (sum of MFU haderived from silage consumption of autumn-spring varieties), silageseed (sum of MFU ha ${ }^{-1}$ derived from autumn variety used for silage and

Table 1. Date of agronomic management growing practices applied to autumn and spring cropping system models under rain-fed and irrigated treatments during the three years (2006, 2007 and 2008) of the assessment.

\begin{tabular}{|c|c|c|c|c|c|c|c|c|}
\hline & & & & A & s (yea) & & & \\
\hline & & n-fed & system & & & gated & syster & \\
\hline & 2005 & 2006 & 2007 & 2008 & 2005 & 2006 & 2007 & 2008 \\
\hline Agronomic practices & & & & & & & & \\
\hline Seedbed preparation & $25 / 09$ & $21 / 09$ & $24 / 09$ & - & $22 / 09$ & $26 / 09$ & $24 / 09$ & - \\
\hline Seed sown & $20 / 10$ & $25 / 10$ & $24 / 10$ & - & $24 / 09$ & $27 / 09$ & $25 / 09$ & - \\
\hline Topdressed fertilisation & - & $03 / 02$ & 06/02 & 08/02 & - & 08/02 & $09 / 02$ & $10 / 02$ \\
\hline Forage harvest & & & & & & & & \\
\hline Legume & - & $11 / 05$ & $14 / 05$ & $12 / 05$ & - & $15 / 05$ & $18 / 05$ & $20 / 05$ \\
\hline Grass & - & $28 / 05$ & $29 / 05$ & $30 / 05$ & - & $3 / 06$ & $06 / 06$ & $04 / 06$ \\
\hline Seed harvest & & & & & & & & \\
\hline Legume & - & $18 / 05$ & $17 / 05$ & $20 / 05$ & - & $31 / 05$ & $01 / 06$ & $31 / 05$ \\
\hline Grass & - & $22 / 05$ & $24 / 05$ & $25 / 05$ & - & $29 / 05$ & $31 / 05$ & $01 / 06$ \\
\hline & & & & Spri & sar) & & & \\
\hline & & ain-fed & systen & & & gated & syste & \\
\hline & 2005 & 2006 & 2007 & 2008 & 2005 & 2006 & 2007 & 2008 \\
\hline Agronomic practices & & & & & & & & \\
\hline Seedbed preparation & - & $30 / 05$ & $30 / 05$ & $31 / 05$ & - & 05/06 & $06 / 06$ & $05 / 06$ \\
\hline Lucerne sown & - & - & - & - & - & $24 / 02$ & - & - \\
\hline Maize and sorghum sown & - & $03 / 06$ & $04 / 06$ & 04/06 & - & 08/06 & 08/06 & $07 / 06$ \\
\hline Thinning date & - & $14 / 07$ & $16 / 07$ & $17 / 06$ & - & $16 / 07$ & $18 / 07$ & $17 / 07$ \\
\hline Topdressed fertilisation & - & $15 / 07$ & $17 / 07$ & $19 / 07$ & - & $18 / 07$ & $19 / 07$ & $18 / 07$ \\
\hline Forage harvest & & & & & & & & \\
\hline Lucerne first cut* & - & - & - & - & - & $24 / 05$ & $29 / 05$ & $26 / 05$ \\
\hline Maize & - & - & - & - & - & $24 / 09$ & $26 / 09$ & $25 / 09$ \\
\hline Sorghum & - & $12 / 09$ & $17 / 09$ & $10 / 09$ & - & $20 / 09$ & $21 / 09$ & $22 / 09$ \\
\hline Seed harvest & & & & & & & & \\
\hline Maize & - & - & - & - & - & $24 / 10$ & $23 / 10$ & $21 / 10$ \\
\hline Sorghum & - & $12 / 10$ & $10 / 10$ & $09 / 10$ & - & $10 / 10$ & $09 / 10$ & $12 / 10$ \\
\hline
\end{tabular}


for seed those sown in spring) and seed-seed (sum of MFU ha ${ }^{-1}$ derived from seed consumption of autumn and spring varieties).

\section{Chemical soil determinations}

In September 2005 before fertilisation and in November 2008 after seed harvest, some soil samples were picked up for chemical tests. The samples were taken from the soil surface (0-35 $\mathrm{cm}$ Ap horizon) using a $60 \mathrm{~mm}$-diameter core sampler. In 2005, 4 harvests were made before ploughing soil grid points of soil selected for the experiment, while in November of 2008 a soil sample was picked up from each plot. The total soil samples harvested were 40 (20 for rain-fed crops and 20 for irrigated crops). Each sample was made by mixing 4 core soils randomly drilled from the plot surface and sieved after an accurate manual root separation with a $2 \mathrm{~mm}$-diameter mesh screen. The soil samples harvested at the beginning (2005) and at end of the experiment (2008) were air-tight sealed and stored in a freezer at $-20^{\circ} \mathrm{C}$ until they were used for the laboratory tests.

The soil chemical parameters assessed were: total $\mathrm{N}$ (Kjeldahl, 1983), OC (Walkley and Black, 1934), P (Olsen et al., 1954), K (UNICHIM, 1985) and pH on a liquid extract of 1:2.5 soil/water solution.

\section{Statistical analyses}

Statistical analyses were conducted on all herbage and seed yield component traits using the SAS PROC ANOVA procedure (1997). The statistical inferences were carried out from all data of the four crop system models for the DM and from data of two models for the SY (model
III and model IV for rain-fed crops and model II and model IV for irrigated crops).

The statistical procedure adopted for data analyses was a factorial experimental design arranged in a split-plot by time (year of evaluation) and space (irrigation treatments). The ANOVA used a mixed model with irrigation, sowing time and crop system models as fixed effects and year and replication as random effects. Furthermore, the data of traits collected during the three years of the experiment under rain-fed and irrigated conditions were processed by Bartlett's homogeneity test (1937). The analysis highlighted no significant variation compared with the test between data of traits recorded under the rainfed and irrigated treatments.

The mean comparison among the traits of the cropping system models was conducted by Duncan's multiple range tests, while the least significant difference (LSD) was calculated with the appropriate error term of ANOVA (Steel and Torrie, 1980).

The levels of the first factor (Y, year), second factor (I, irrigation), third factor (S, sowing time) and forth factor (M, cropping system model) were $3,2,2$ and 4 , respectively. The variability of the traits over the years among crop system models of rain-fed crops and irrigated crops was assessed by standard error determination (reported as vertical bars on traits of Figures 2A-C and 3A, B). The chemical parameters of the topsoil were analysed according to a factorial split-plot design with irrigation as main plot and the cropping system models and the determination made before the beginning of experiment as subplots with four replications. In the statistical analysis, the irrigation was assumed as first factor with 2 levels; and the cropping system models

Table 2. Crop species, variety name and agronomic management used in autumn and spring cropping system models evaluated with rain-fed and irrigated treatments in the European Mediterranean environment.

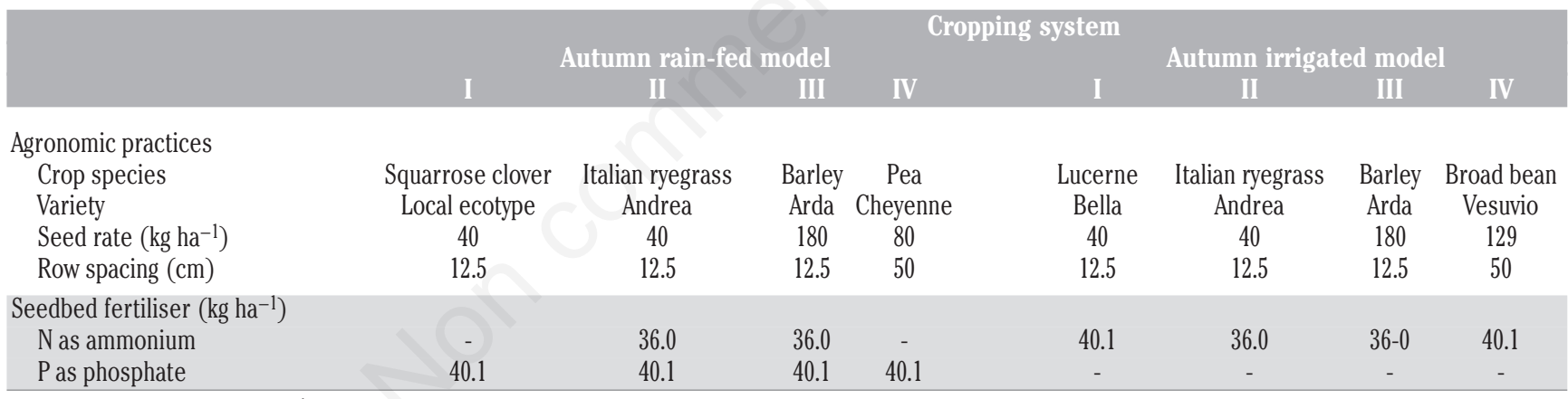

Topdressed fertiliser $\left(\mathrm{kg} \mathrm{ha}^{-1}\right)$

$\mathrm{N}$ as urea

$60 \quad 60$

60

60

\begin{tabular}{|c|c|c|c|c|c|c|c|c|}
\hline & \multicolumn{3}{|c|}{ Spring rain-fed model } & \multicolumn{2}{|c|}{ Cropping system } & \multicolumn{2}{|c|}{ Spring irrigated model } & \multirow[b]{2}{*}{ IV } \\
\hline & I & II & III & IV & I & II & III & \\
\hline \multicolumn{9}{|l|}{ Agronomic practices } \\
\hline Crop species & Grain sorghum & $\begin{array}{c}\text { Silage } \\
\text { sorghum }\end{array}$ & $\begin{array}{c}\text { Silage } \\
\text { sorghum }\end{array}$ & $\begin{array}{l}\text { Grain } \\
\text { sorghum }\end{array}$ & Lucerne & Maize & Silage sorgum & $\begin{array}{l}\text { Grain } \\
\text { sorghum }\end{array}$ \\
\hline Variety & Regulus & Nicol & Nicol & Regulus & Bella & Azuaga & Nicol & Regulus \\
\hline Row spacing $(\mathrm{cm})$ & 60 & 60 & 60 & 60 & 12.5 & 60 & 60 & 60 \\
\hline Plant density (plant $\mathrm{m}^{-2}$ ) & 20 & 35 & 35 & 20 & - & 10 & 40 & 25 \\
\hline \multicolumn{9}{|l|}{ Seedbed fertiliser $\left(\mathrm{kg} \mathrm{ha}^{-1}\right)$} \\
\hline $\mathrm{N}$ as ammonium & 36 & 36 & 36 & 36 & - & 36 & 36 & 36 \\
\hline P as phosphate & 41 & 41 & 41 & 41 & - & 96 & 96 & 96 \\
\hline \multicolumn{9}{|l|}{ Topdressed fertiliser $\left(\mathrm{kg} \mathrm{ha}^{-1}\right)$} \\
\hline $\mathrm{N}$ as urea & 70 & 70 & 70 & 70 & - & 130 & 110 & 110 \\
\hline P as phosphate & - & - & - & - & 41.9 & - & - & - \\
\hline
\end{tabular}


and the initial determination as second factor with 5 levels. The comparisons of the means of the cropping system models between determinations at the beginning and at end of experiment were made using the LSD at $P \geq 0.05$ and 0.01 probability levels calculated on the error term of the ANOVA. Furthermore, the data of legume and grass models under rain-fed and irrigated conditions were analysed by factorial design with two factors (crop species: legume and grass) and two levels (legume: model I and model IV and grass: model II and model III). The comparisons of the means of legume and grass models were established using the LSD at 0.05 and 0.01 probability levels.

\section{Results}

The ANOVA revealed a significant effect of main factors: year, irrigation, sowing time and cropping system models in all DM and SY component traits (Tables 3 and 4). Although the year appears as a significant factor, the effect of the climate did not express quantitatively a significant variation of data according to Bartlett's homogeneity test (1937). Thus the results of the experiment reported in the text, the tables and the figures will be referred to as means over the years.

Table 3. Mean squares of herbage traits: dry matter (DM) $\left(\mathrm{kg} \mathrm{m}^{-2}\right)$, moisture at harvest $(\%)$, plant height $(\mathrm{cm}), \mathrm{stems}^{-2}(\mathrm{n})$, milk feed

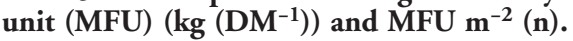

\begin{tabular}{|c|c|c|c|c|c|c|c|}
\hline Source & df & DM & Moisture & Plant height & Stems $\mathrm{m}^{-2}$ & MIFU & MFU m-2 \\
\hline Y & 2 & $1012 * *$ & $36.1^{* *}$ & $977^{* *}$ & $71,171^{* *}$ & $0.08^{* *}$ & $727^{* *}$ \\
\hline I & 1 & $1893^{* *}$ & $11,701^{* *}$ & $756^{* *}$ & $19,936^{* *}$ & $0.04^{* *}$ & $1093^{* *}$ \\
\hline S & 1 & $456^{* *}$ & $999 * *$ & $3267 * *$ & $111,319 * *$ & $0.02 * *$ & $310^{* *}$ \\
\hline M & 3 & $4109 * *$ & $449 * *$ & $1143^{* *}$ & $212,166^{* *}$ & $0.03^{* *}$ & $2917 * *$ \\
\hline \multicolumn{8}{|c|}{ Interaction } \\
\hline $\mathrm{IxY}$ & 2 & $1893^{* *}$ & $311^{* *}$ & $1704^{* *}$ & $83,545^{* *}$ & $0.006^{*}$ & $0.006^{*}$ \\
\hline IxM & 3 & $1460 * *$ & $21 \mathrm{~ns}$ & $163 \mathrm{~ns}$ & $5299 \mathrm{~ns}$ & $0.12^{* *}$ & $813^{* *}$ \\
\hline IxS & 1 & $650 * *$ & $52^{* *}$ & $1457^{* *}$ & $123,779 * *$ & $0.008^{*}$ & $118^{* *}$ \\
\hline $\mathrm{MxY}$ & 6 & $67 \mathrm{~ns}$ & $134^{* *}$ & $1096^{* *}$ & $21,373^{* *}$ & $0.004 \mathrm{~ns}$ & $319^{* *}$ \\
\hline SxM & 3 & $432^{* *}$ & $25^{* *}$ & $6051^{* *}$ & $286,026^{* *}$ & $0.04^{* *}$ & $295^{* *}$ \\
\hline $\mathrm{SxY}$ & 2 & $1514^{* *}$ & $109 * *$ & $1870^{* *}$ & $47,747^{* *}$ & $0.006^{*}$ & $686^{* *}$ \\
\hline IxSxM & 3 & $426^{* *}$ & $5.3 \mathrm{~ns}$ & 499 ns & $8668 \mathrm{~ns}$ & $0.06^{*}$ & $1330 * *$ \\
\hline IxMxY & 6 & $90 \mathrm{~ns}$ & $20.2 \mathrm{~ns}$ & $185 \mathrm{~ns}$ & $5438 \mathrm{~ns}$ & $0.004 \mathrm{~ns}$ & $172 \mathrm{~ns}$ \\
\hline IxSxY & 2 & $61 \mathrm{~ns}$ & $22 \mathrm{~ns}$ & $493^{*}$ & $1197 \mathrm{~ns}$ & $0.09 * *$ & $3 \mathrm{~ns}$ \\
\hline MxSxY & 6 & $62 \mathrm{~ns}$ & $6.2 \mathrm{~ns}$ & $206 \mathrm{~ns}$ & $3131 \mathrm{~ns}$ & $0.03 \mathrm{~ns}$ & $38 \mathrm{~ns}$ \\
\hline IxMxSxY & 6 & $70 \mathrm{~ns}$ & $3.5 \mathrm{~ns}$ & $186 \mathrm{~ns}$ & $5230 \mathrm{~ns}$ & $0.004 \mathrm{~ns}$ & $37 \mathrm{~ns}$ \\
\hline Error & 141 & 42 & 9.47 & 162.7 & 2673 & 0.002 & 30 \\
\hline
\end{tabular}

df, degree of freedom; DM, dry matter; MFU, milk feed unit; Y, year; I, irrigation; S, seeding; M, model; ns, not significant. *,** Statistical significant at P $\geq 0.05$ and P $\geq 0.01$ probability level, respectively.

Table 4. Mean squares of the grain traits: seed yield $\left(\mathrm{kg} \mathrm{m}^{-2}\right)$, moisture at harvest $(\%)$, seed weight (g), harvest index $(\%)$, milk feed unit (MFU) $\left(\mathrm{kg}(\mathrm{DM})^{-1}\right)$ and MFU $\mathrm{m}^{-2}(\mathbf{n})$.

\begin{tabular}{|c|c|c|c|c|c|c|c|}
\hline Source & df & SY & Moisture & Seed weight & HI & MFU & MFU m-2 \\
\hline Y & 2 & $132 * *$ & $125^{* *}$ & $20,813^{* *}$ & $2417 * *$ & $0.025^{* *}$ & $82,706^{* *}$ \\
\hline I & 1 & $602^{* *}$ & $1645^{* *}$ & $41,399 * *$ & $1550^{* *}$ & $0.03^{* *}$ & $15,487^{* *}$ \\
\hline S & 1 & $298^{* *}$ & $305^{* *}$ & $544^{* *}$ & $992 * *$ & $0.013^{* *}$ & $57,942 * *$ \\
\hline M & 1 & $1302^{* *}$ & $1398 * *$ & $14,778^{* *}$ & $1518^{* *}$ & $0.03^{* *}$ & $28,498^{* *}$ \\
\hline \multicolumn{8}{|c|}{ Interaction } \\
\hline IxM & 1 & $8.9 *$ & $61^{* *}$ & $1080^{*}$ & $814^{* *}$ & $0.01^{* *}$ & $4465^{* *}$ \\
\hline IXS & 1 & $325^{* *}$ & $208^{* *}$ & $10,253^{* *}$ & $1427^{* *}$ & $0.04 * *$ & $81,954^{* *}$ \\
\hline $\mathrm{IxY}$ & 2 & $140^{* *}$ & $457^{* *}$ & $16,058^{* *}$ & $553^{* *}$ & $0.002 \mathrm{~ns}$ & $61,762^{* *}$ \\
\hline $\mathrm{MxS}$ & 1 & $408^{* *}$ & $14 \mathrm{~ns}$ & $5698 * *$ & $484^{* *}$ & $0.002 \mathrm{~ns}$ & $57,514^{* *}$ \\
\hline $\mathrm{MxY}$ & 2 & $39 \mathrm{~ns}$ & $182^{* *}$ & $9610^{* *}$ & $406^{* *}$ & $0.005^{* *}$ & $4677 \mathrm{~ns}$ \\
\hline $\mathrm{SxY}$ & 2 & $491^{* *}$ & $170^{* *}$ & $4059^{* *}$ & $253^{* *}$ & $0.02^{* *}$ & $61,762^{* *}$ \\
\hline IxMxS & 1 & $556^{* *}$ & $213^{* *}$ & $17,725^{* *}$ & $134^{* *}$ & $0.001 \mathrm{~ns}$ & $71,572^{* *}$ \\
\hline IxMxY & 2 & $581^{* *}$ & $39 *$ & $8869^{* *}$ & $173^{* *}$ & $0.005^{* *}$ & $76,007^{* *}$ \\
\hline IxSxY & 2 & $839 * *$ & $114^{* *}$ & $5435^{* *}$ & $446^{* *}$ & $0.01^{* *}$ & $13,942 *$ \\
\hline MxSxY & 2 & $15 \mathrm{~ns}$ & $29 \mathrm{~ns}$ & $1445^{* *}$ & $583^{* *}$ & $0.002 \mathrm{~ns}$ & $16,126^{*}$ \\
\hline IxMxSxY & 2 & $62 \mathrm{~ns}$ & $65^{* *}$ & $682 \mathrm{~ns}$ & $6871^{* *}$ & $0.001 \mathrm{~ns}$ & 8219 ns \\
\hline Error & 69 & 26.6 & 9.8 & 232.1 & 21.6 & 0.001 & 3738 \\
\hline
\end{tabular}

df, degree of freedom; SY, seed yield; HI, harvest index; MFU, milk feed unit; Y, year; I, irrigation; S, seeding; M, model; ns, not significant. **** Statistical significant at P $\geq 0.05$ and P $\geq 0.01$ probability level, respectively. 
The significant mean square values observed in DM and SY traits of two- $(\mathrm{M} \times \mathrm{Y})$, three- $(\mathrm{I} \times \mathrm{M} \times \mathrm{Y})$ and four- $(\mathrm{IxMxSxY})$ way interaction factors were ascribed to relationships among experimental factors related to the development of varieties of the models (Tables 3 and 4).

The reduced effect of irrigation on the DM mean of autumn-sown models ( $7.63 \mathrm{t} \mathrm{ha}^{-1}$ rain-fed $v s 10.87 \mathrm{tha}^{-1}$ irrigated) in comparison to the varieties sown in spring was due to the physiological peculiarity of varieties (C4 instead C3 plant) in the weather conditions of the habitats which promoted the plant growth during months with favourable meteorological conditions for DM (14.87 tha ${ }^{-1}$ rain-fed $v s 23.77 \mathrm{t} \mathrm{ha}^{-1}$ irrigated) (Figure 2A).

The DM values in the autumn-sown crop system models range from $4.86 \mathrm{t} \mathrm{ha}^{-1}$ (model IV) to $10.33 \mathrm{t} \mathrm{ha}^{-1}$ (model III) under rain-fed conditions and from $9.86 \mathrm{t} \mathrm{ha}^{-1}$ (model II) to $12.55 \mathrm{t} \mathrm{ha}^{-1}$ (model III) with irrigation, while in spring sowing models the range was increased under both treatments (11.13 $\mathrm{t} \mathrm{ha}^{-1}$ in model I to $21.83 \mathrm{t} \mathrm{ha}^{-1}$ in model III under rain-fed conditions and $17.56 \mathrm{t} \mathrm{ha}^{-1}$ in model IV to $28.92 \mathrm{t} \mathrm{ha}^{-1}$ in model II with irrigation) (Figure 2A). The lower standard errors of the observations in all traits (trait vertical bars in the figures) of autumnsown and spring-sown models with irrigation treatment compared with those under rain-fed conditions were due to the effect of irrigation on the plants which reduced the variability in terms of development (Figures 2 and 3).

The DM and MFU traits in autumn models in comparison to those sown in spring were reduced by $51.6 \%$ and $54.5 \%$ under rain-fed conditions and $58.1 \%$ and $62.9 \%$ with the irrigation treatment respectively (Figure 2A, C), while an opposite trend was observed in moisture in the harvest trait. The harvest moisture of autumn-sown varieties under rain-fed conditions and treated with irrigation was 5.8\% and $2.0 \%$ higher than that of varieties sown in spring respectively (Figure 2B). The reduced gap in terms of moisture between the rain-fed and the irrigated treatment of autumn-sown and spring-sown models was a consequence of the effect of weather and the duration of the vegetative cycle on the plant development of the varieties (Figure 2B).

The MFU of varieties sown in autumn and those in spring crop system models range from 0.68 to 0.83 with irrigation and from 0.60 to 0.79 with the rain-fed treatment (Figure 2C). The reduced mean value of MFU in rain-fed models (2.1\% in autumn-sown varieties and $5.2 \%$ in spring-sown varieties) was a consequence of the effect of irrigation on plant development and plant density (Figure 2C). The MFU in autumn and spring crop system models with the same varieties (model II and model III for autumn-sown varieties and model III and model IV for
A

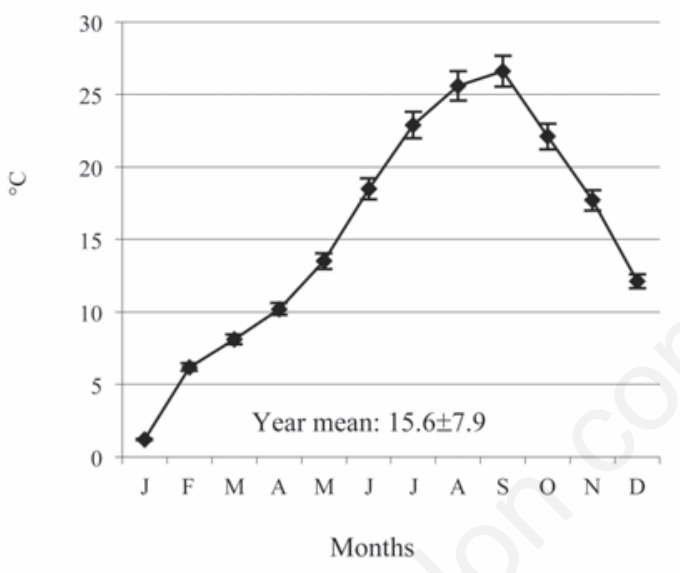

B

Solar radiation

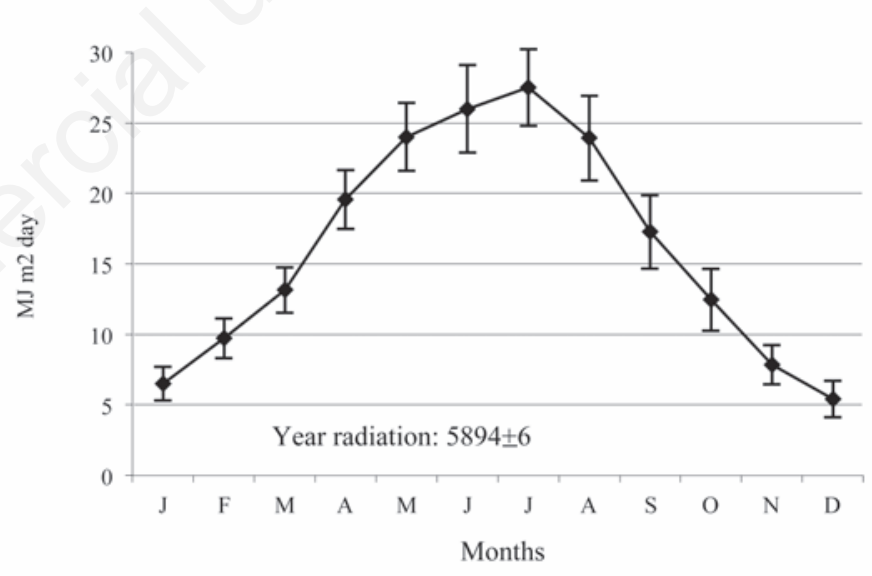

C

Rainfall

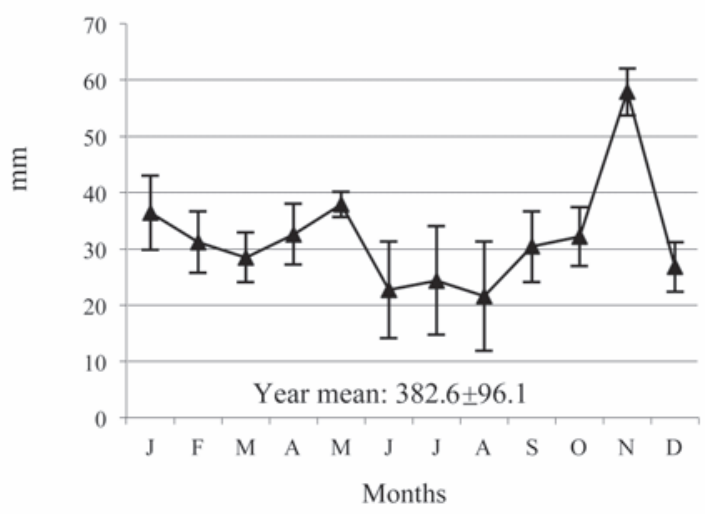

D

Water evaporation

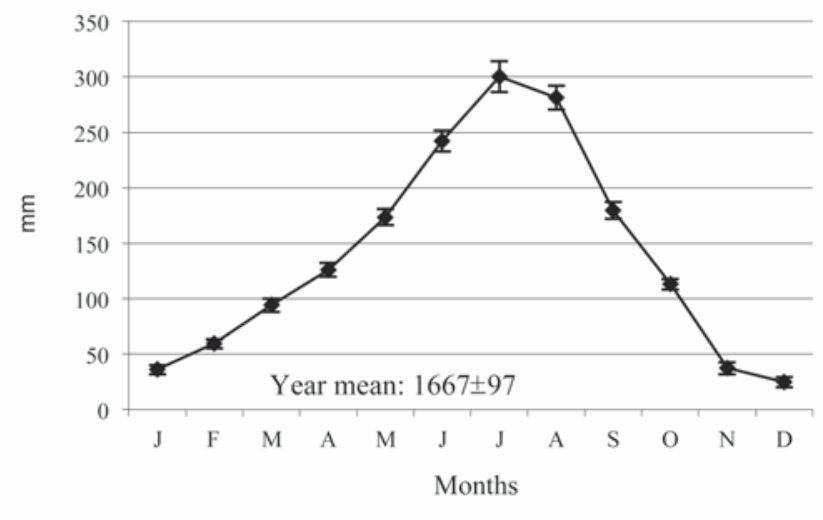

Figure 1. Three-year monthly means (2006, 2007 and 2008) and their standard error (vertical bar) of meteorological characteristics: temperature (A), solar radiation (B), rainfall (C) and water evaporation (D). 
A

Silage dry matter

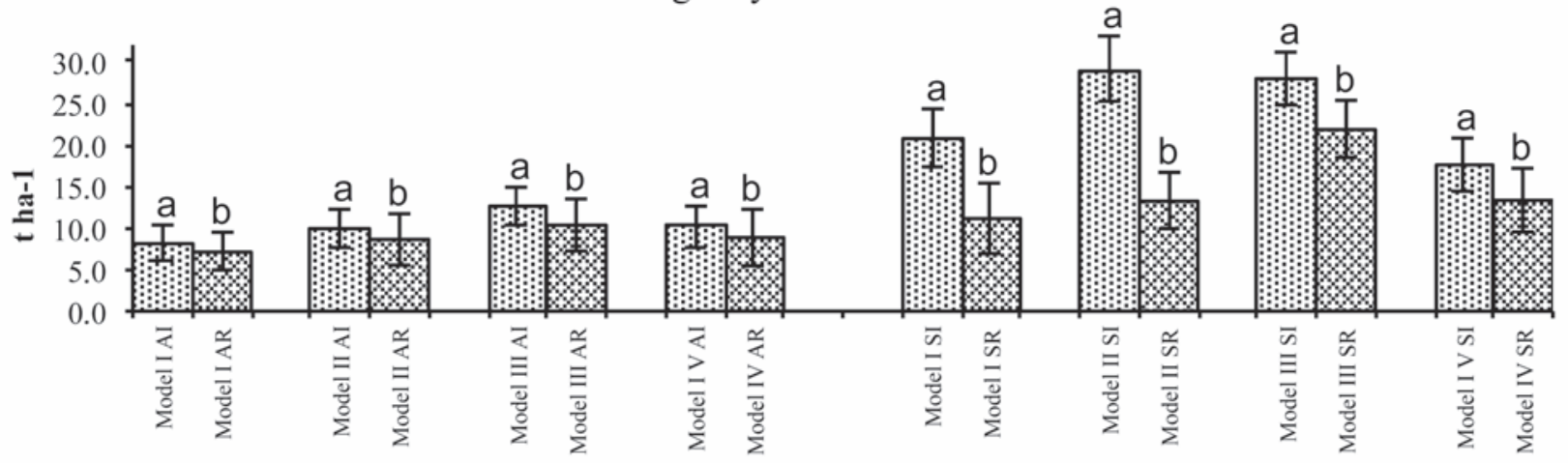

Rainfed and irrigated autumn and spring cropping system models

B

Moisture at harvest

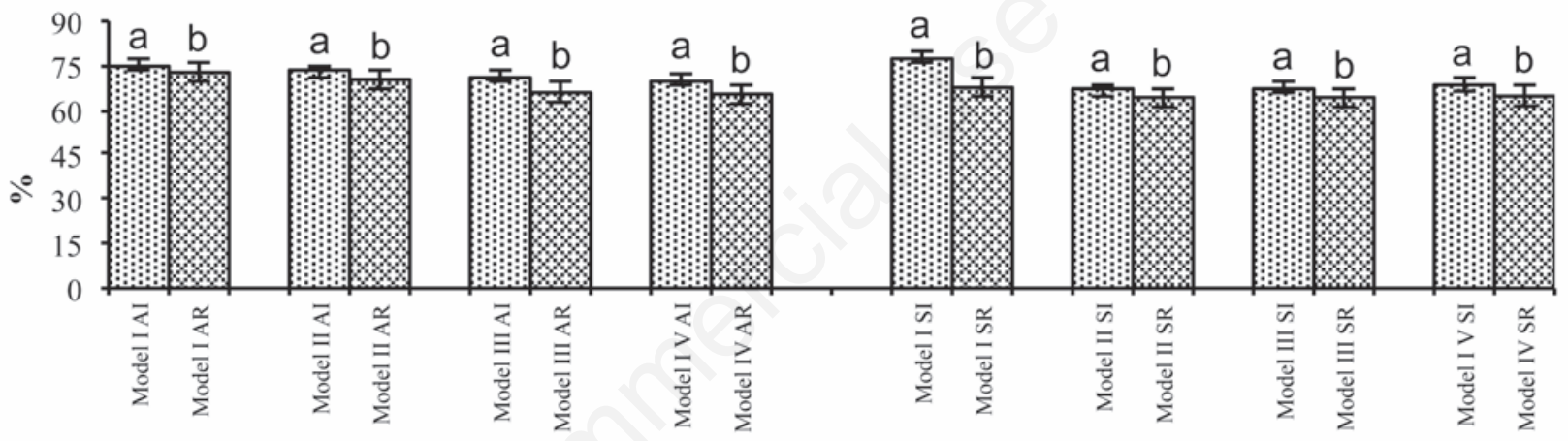

Rainfed and irrigated autumn and spring cropping system models

C

Milk forage unit

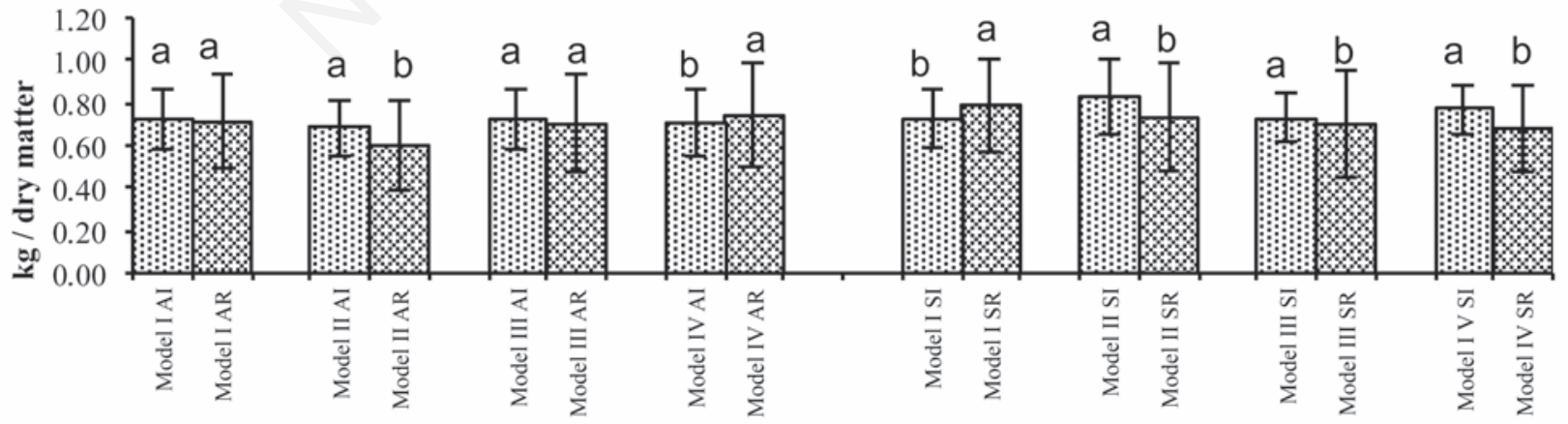

Rainfed and irrigated autumn and spring cropping system models

Figure 2. Mean over years and their standard error (vertical bar) through the period of evaluation of silage dry matter (A), moisture at harvest (B) and milk forage unit (C) in autumn (A) and spring (S) forage crop models (model I, model II, model III and model IV) under rain-fed $(\mathrm{R})$ and irrigated $(\mathrm{I})$ conditions. Means trait of the same genotype in model under rain-fed and irrigated treatments with same letter are not significant at Duncan's multiple-range test at $P \geq 0.05$ level of probability. 
spring-sown varieties) was higher in the models under irrigated treatment than in those under rain-fed conditions, i.e. $11.8 \%$ in model II and $2.8 \%$ in model III in autumn and $4.1 \%$ in model III and $11.6 \%$ in model IV in spring (Figure 2C).

In autumn models (model II and model III) and spring models (model III and model IV) with common varieties, the mean of plant height and stem density was higher with irrigation than under rain-fed

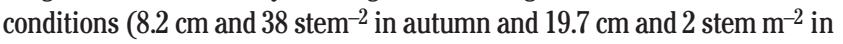
spring, respectively) (Figure 3). Wider variation in the plant height was observed in model III of both sowing times (irrigated treatment was higher by $20.9 \%$ in autumn and $11.3 \%$ in spring compared with the rain-fed approach) (Figure 3A). The variation of the stem $\mathrm{m}^{-2}$ trait was wider in spring models than in autumn models (3.7\% in model II and $5.4 \%$ in model III in autumn and over $6 \%$ in model III and model IV in spring) (Figure 3B).
The effect of the water supply on the models made with common varieties of sown in autumn (barley) and in spring (grain maize and sorghum) increased significantly the SY and the seed weight $(18.2 \%$ and $3.9 \%$ in model III of autumn-sown varieties and $73.7 \%$ and $64.9 \%$ in model IV of spring-sown varieties, respectively) while the HI trait was less influenced by irrigation than by the rain-fed treatment (Table 5). The MFU mean in SY, in spring model II and model IV, was $8.1 \%$ and $4.5 \%$ higher than those of autumn models (model III and model IV) under irrigated and rain-fed conditions, respectively. No variation was found in the MFU trait between varieties of autumn and spring models (Table 5). The mean of total silage-silage MFU ha ${ }^{-1}$ of autumn-spring sown models was $8.3 \%$ and $48.9 \%$ higher with irrigation and $18.1 \%$ and $68.1 \%$ higher under rain-fed conditions than silage-seed and seed-seed utilisation, respectively (Table 6). The effect of irrigation on MFU ha ${ }^{-1}$ in seed-seed utilisation, in comparison to those of silage-silage, was

A

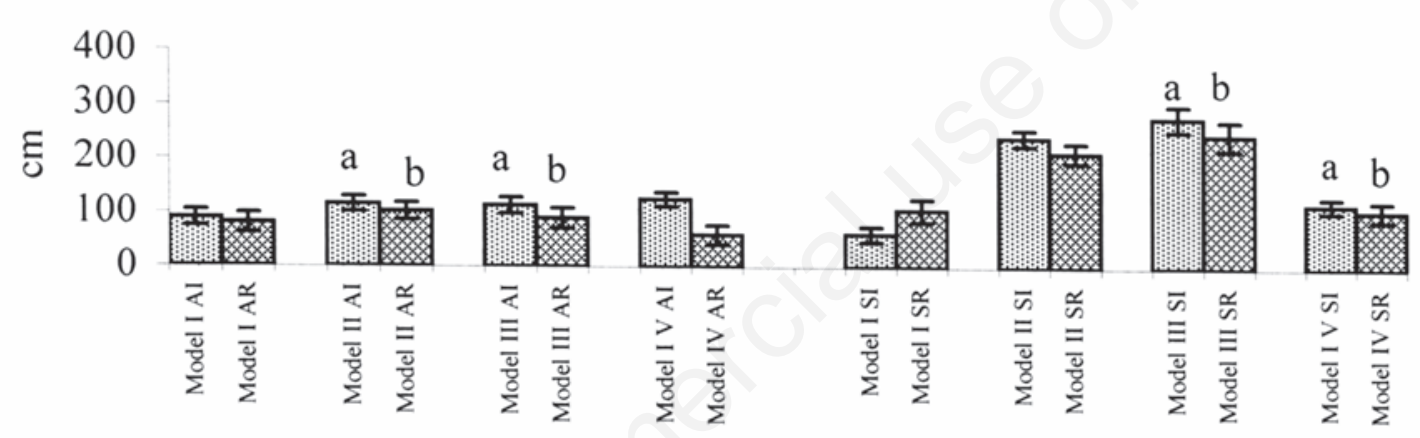

Rainfed and irrigated autumn and spring cropping system models

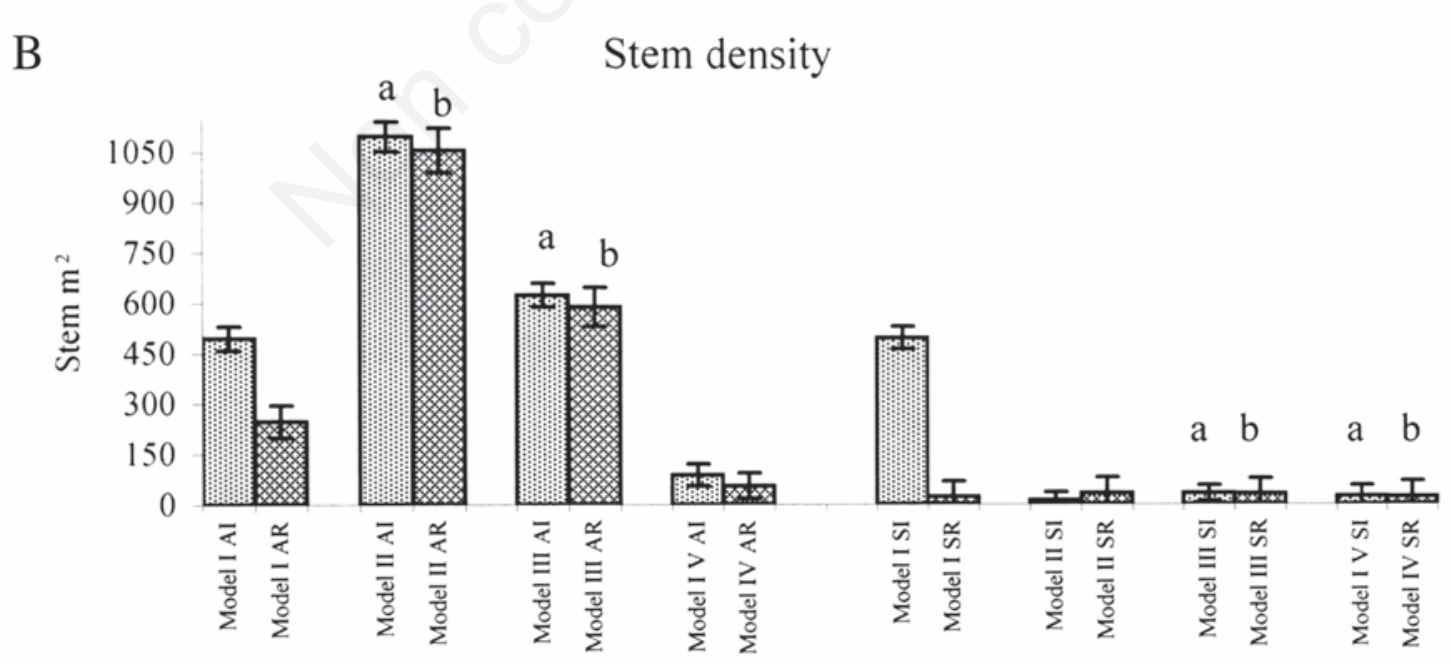

Rainfed and irrigated autumn and spring cropping system models

Figure 3. Plant height (A) and stem density (B) yearly mean of common varieties and their standard error through the time of valuation (vertical bar) of autumn (A) and spring (S) crop system models (model I, model II, model III and model IV) under rain-fed (R) and irrigated (I) treatment. Means trait of the common varieties under rain-fed and irrigated treatment, with same letter are not significant at Duncan's multiple-range test at $\mathrm{P} \geq \mathbf{0 . 0 5}$ level of probability. 
reduced by $38.8 \%$ and $61.7 \%$ in the rain-fed and irrigated models, respectively (Table 6).

The MFU ha ${ }^{-1}$ of silage-silage utilisation of the cropping system treated with irrigation of model II was $45.0 \%, 1.5 \%$ and $41.3 \%$ higher than in model I, model III and model IV, respectively while the variation of MFU ha ${ }^{-1}$ among of rain-fed models showed a different trend (model III was $24.7 \%, 19.9 \%$ and $36.5 \%$ higher than model I, II and IV, respectively). The highest MFU ha ${ }^{-1}$ from silage-seed utilisation was obtained in model III treated with irrigation $(16.7 \%$ and $43.4 \%$ higher than models II and IV) and in model II under rain-fed conditions (59.3\% and $68.6 \%$ higher than model I and model IV, respectively) (Table 6).

The discrepancy of MFU ha'-1 (difference between highest and lowest mean trait among models with the same agronomic treatment) in silage-silage utilisation under irrigation, in comparison to that of silage-seed under rain-fed conditions, was higher among models with irrigation than those of rain-fed models (13,853 vs 11,989 with irrigation and 6578 vs 14,456 under rain-fed conditions) (Table 6). The higher discrepancy observed between the mean of MFU ha ${ }^{-1}$ in crop system models used for silage-seed and seed-seed consumption under rain-fed conditions compared with those with the irrigated treatment $(14,456$ and 11,989 in silage-seed and 10,603 and 2053 in seed-seed utilisation, respectively) was a consequence of the weather on seed production (Table 6). The effect of irrigation compared with the rain-fed treatment in autumn and spring crop system models was respectively higher than $27.6 \%$ and $42.4 \%$ for silage and $37.9 \%$ and $66.1 \%$ in seed utilisation (calculations based on data reported in Figure 2A, C).

Table 5. Seed yield in autumn and spring cropping system models under rain-fed and irrigated conditions.

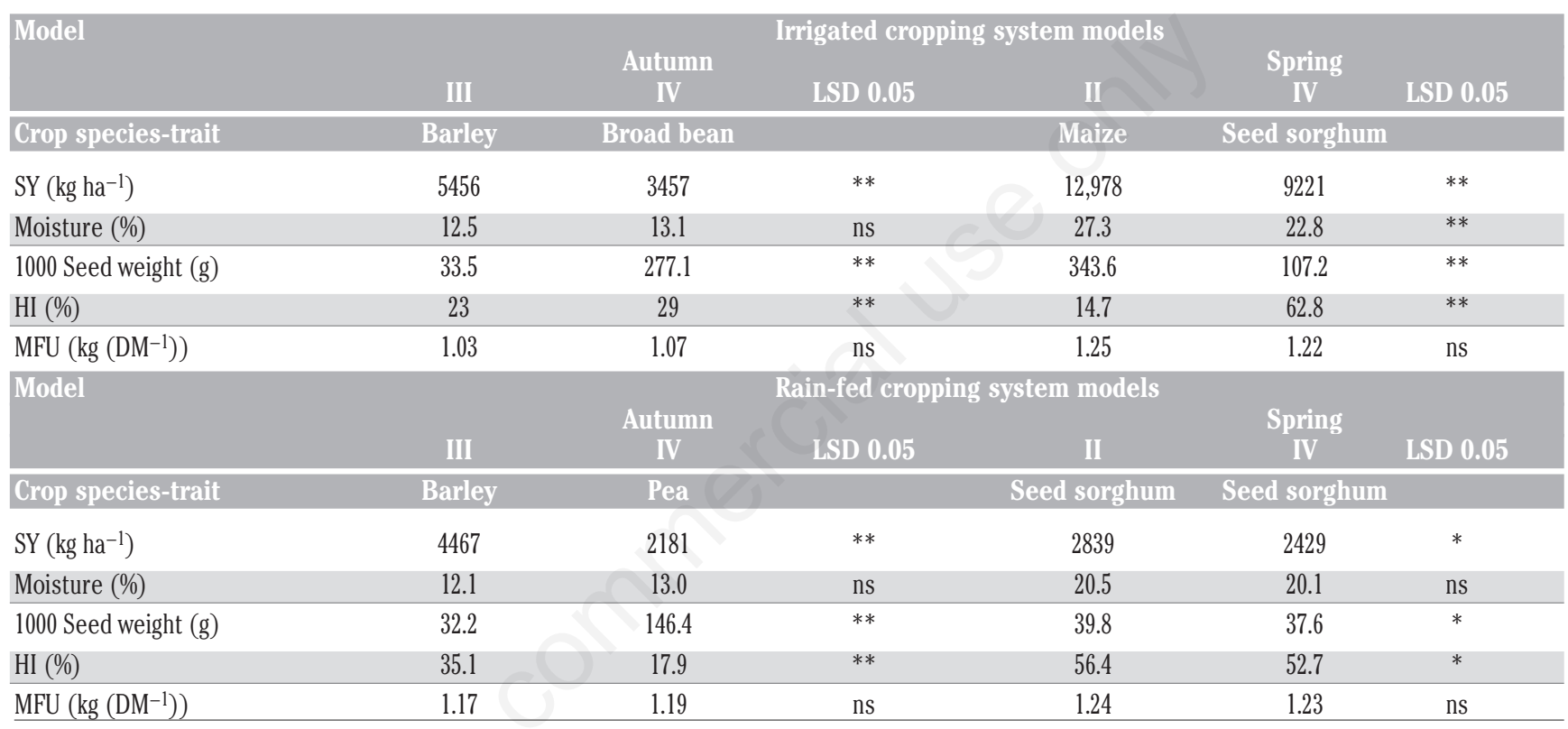

LSD, least significant difference test; SY, seed yield; ns, not significant; HI, harvest index; MFU, milk feed unit. **** Statistical significant at $\mathrm{P} \geq 0.05$ and $\mathrm{P} \geq 0.01$ probability level, respectively.

Table 6. Milk feed unit ha ${ }^{-1}$ production of crop system models (sum of autumn and spring model) according to fodder forage utilisation (silage-silage, silage-seed and seed-seed).

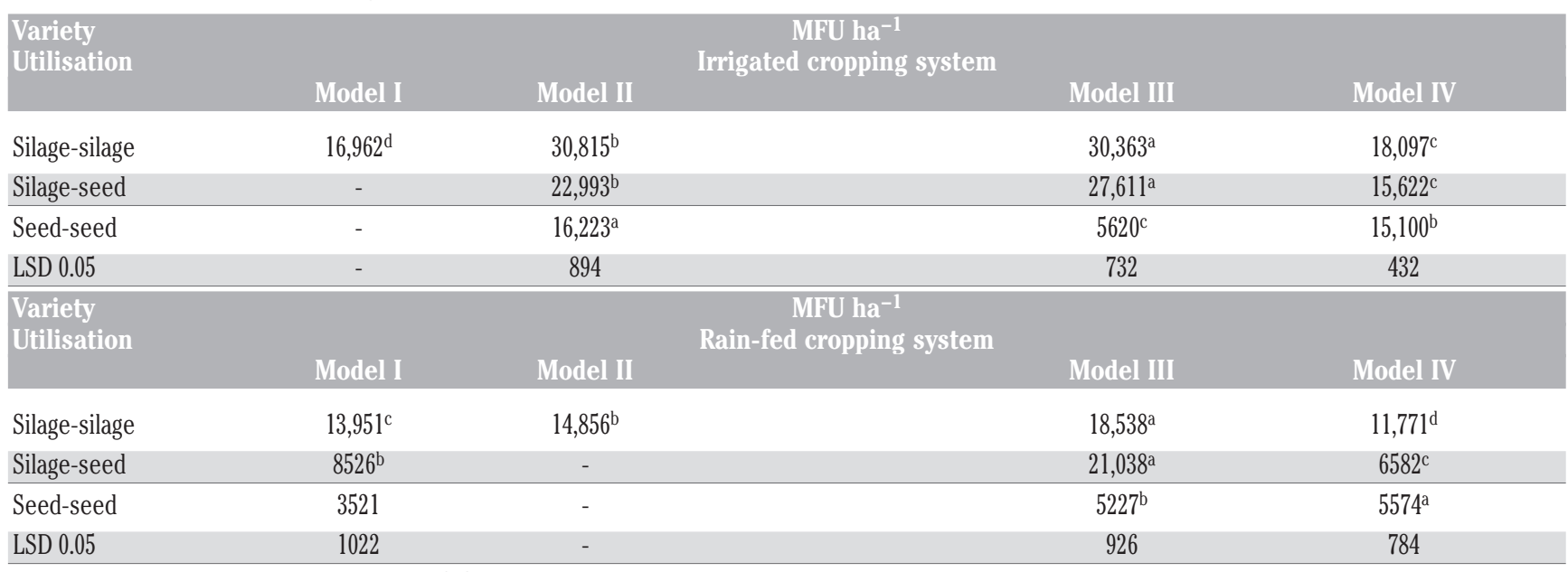

MFU, milk feed unit; LSD, least significant difference test. ab,c,dAmong the cropping system models, the means with the same letter are not statistically significant in Duncan's multiple-range test at P $\geq 0.05$ level of probability. LSD threshold confidential limits of statistical significant among cropping system model utilisations at $P \geq 0.05$ probability level. 
The agronomic impact of the continuous rotation over a period of three years strongly influenced the initial content of topsoil biochemical characteristics (Table 7). The OC content at the beginning of the experiment $\left(14.67 \mathrm{~g} \mathrm{~kg}^{-1}\right)$ under rain-fed conditions was higher in the cropping system with autumn-sown grasses and spring models $(1.80 \mathrm{~g}$ $\mathrm{kg}^{-1}$, model II and model III) than in those with legumes $\left(0.81 \mathrm{~g} \mathrm{~kg}^{-1}\right.$, mean over model I and model IV), while under the irrigation treatment the reduction was $2.5 \mathrm{~g} \mathrm{~kg}^{-1}$ for grasses and $0.06 \mathrm{~g} \mathrm{~kg}^{-1}$ for legumes (Table 7). The reduction of OC (mean for the legume and grass models) in legume and grass crop system was $0.99 \mathrm{~g} \mathrm{~kg}^{-1}$ under rain-fed conditions and $2.44 \mathrm{~g} \mathrm{~kg}^{-1}$ with the irrigation treatment (Table 7). By contrast, the $\mathrm{OC}$ in the crop system with the perennial legume lucerne increased compared with the initial content by $1.51 \mathrm{~g} \mathrm{~kg}^{-1}$ (Table 7). However, the lack of the initial content of $\mathrm{OC}$ at end of the experiment was related to the MFU ha ${ }^{-1}$ produced by the crop system models (2.90, 2.09 and $1.28 \mathrm{~g} \mathrm{~kg}^{-1}$ in a model II, III and IV with irrigation and 0.52 , $1.80,1.86$ and $1.04 \mathrm{~g} \mathrm{~kg}^{-1}$ in model I, II, III and IV under rain-fed conditions, respectively) (Tables 5 and 7 ). The $\mathrm{N}$ content (mean of the models) at end of trial was reduced by $0.08 \mathrm{~g} \mathrm{~kg}^{-1}$ under rain-fed conditions and $0.17 \mathrm{~g} \mathrm{~kg}^{-1}$ with the irrigation treatment. The lower content of $\mathrm{N}$ in the crop system models with irrigation compared with the rain-fed ones was a consequence of the higher nutrient requirements of the aerial biomass to sustain the DM and the SY under irrigated condition (Figure 2A; Table 5). The difference between mean values of $\mathrm{C} / \mathrm{N}$ ratio in models with annual legumes and those with grasses varieties under rain-fed conditions and irrigated treatment was 1.15 and 0.9 respectively (Table 7). The lower content in $\mathrm{C} / \mathrm{N}$ in the grass models versus the legume models under rain-fed conditions and irrigated treatment (11.7\% and $12.6 \%$, respectively) was inversely proportional to the DM production of the crop systems (autumn legume models $7.85 \mathrm{tha}^{-1}$ and $9.20 \mathrm{t} \mathrm{ha}^{-1}$; and spring grass models $14.86 \mathrm{tha}^{-1}$ and $23.76 \mathrm{t} \mathrm{ha}^{-1}$ under rain-fed conditions and irrigated treatment, respectively) (Figure 2A).

At the end of experiment, the initial $P$ value in the crop system models with legumes was reduced by $5.8 \mathrm{mg} \mathrm{kg}^{-1}$ under irrigation and 4.1 $\mathrm{mg} \mathrm{kg}{ }^{-1}$ under rain-fed treatment, while a more significant reduction was observed for $\mathrm{K}$ in the crop system models with autumn legume and grass varieties $\left(866 \mathrm{mg} \mathrm{kg}^{-1}\right.$ and $881 \mathrm{mg} \mathrm{kg}^{-1}$ in grasses and 908 and $953 \mathrm{mg} \mathrm{kg}^{-1}$ in legumes under irrigated and rain-fed conditions respectively) (Table 7). The mean variation of $\mathrm{P}$ and $\mathrm{K}$ content in the topsoil of the cropping system models with legume and grasses varieties (20.3 and $21.4 \mathrm{mg} \mathrm{kg}^{-1}$ for $\mathrm{P}$ and 481 and $522 \mathrm{mg} \mathrm{kg}^{-1}$ for $\mathrm{K}$ under irrigation management; and 21.9 and $22.3 \mathrm{mg} \mathrm{kg}^{-1}$ for $\mathrm{P}$ and 435 and $507 \mathrm{mg} \mathrm{kg}^{-1}$ for $\mathrm{K}$ under rain-fed treatment respectively) was a consequence of the their role in the biochemical pathways of OC mineralisation (Table 7).

The $\mathrm{pH}$ values in the treatments range from 8.0 to 8.2. This trait was statistically significant in legume models under irrigated treatment and not significant in grass models under rain-fed and irrigated treatment (Table 7).

Table 7. Mean value of soil parameters at the beginning of the experiment $v$ s at end of autumn and spring forage cropping system models established under irrigated and rain-fed conditions.

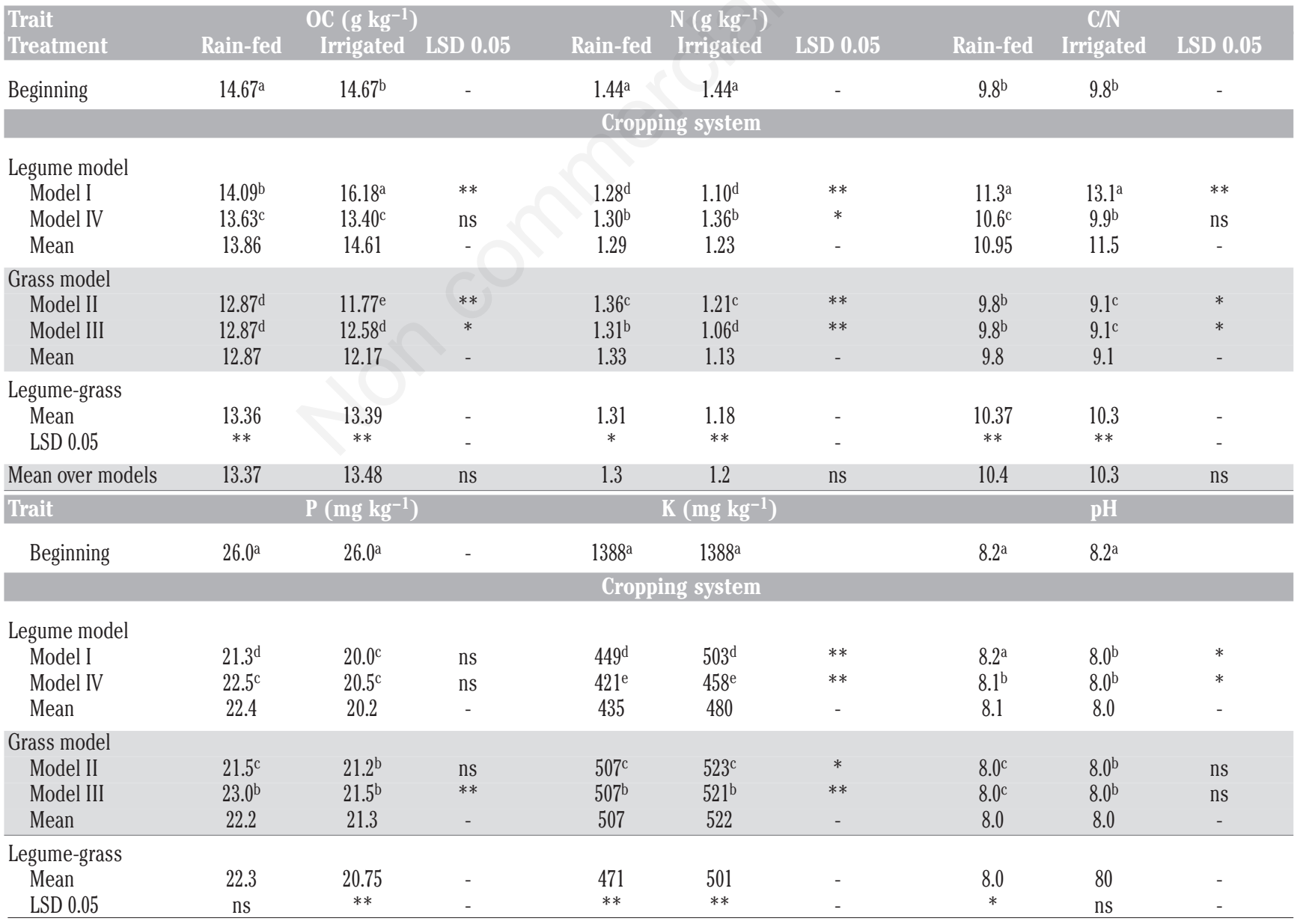

OC, organic carbon; N, nitrogen; C/N, carbon/nitrogen ratio; LSD, least significant difference test; ns, not significant; P, phosphorus; K, potassium. a,b,c,d,e Among cropping system models, the means of traits under rain-fed and irrigated treatments with the same letter are not statistically significant in Duncan's multiple-range test at $P \geq 0.05$ level of probability. ${ }^{* * *}$ Statistically significant at $P \geq 0.05$ and 0.01 probability level, respectively. 


\section{Discussion}

The lack of statistically significant two- $(\mathrm{M} \times \mathrm{Y})$, three- $(\mathrm{I} \times \mathrm{M} \times \mathrm{Y})$ and four-way (IxMxSxY) interaction factors in DM, SY and their yield component traits were due to the combined effect of weather characteristics with agronomic factors on the plant development of autumn- and spring-sown varieties in the crop system models (Tables 3 and 4).

The lower variation throughout the period (standard error) among the trait mean values of DM, SY, MFU, plant height and stem $\mathrm{m}^{-2}$ under rain-fed and irrigation treatments in autumn model compared with spring models was a consequence of the vegetative performance of the varieties which grew during months with available natural resources (water and weather characteristics) that were favourable to plant development (Figures 1 and 2A; Table 5).

The rain-fed effect (expressed as percentage reduction of the varieties under rain-fed over those under irrigated) in autumn and spring models weakened the physiological process in the organs of the plant causing a reduction of DM, SY, moisture at harvest, MFU, plant height and stem density (Figures 2A, C and 3; Table 5). Therefore the comparison between the rain-fed and irrigated treatments showed that the yearly mean of sorghum cropping system decreases for DM in model III (21.81 t ha' $\mathrm{t}^{-1}$ rain-fed $v s 27.84 \mathrm{t} \mathrm{ha}^{-1}$ irrigated) and for SY in model IV (2.63 $\mathrm{t} \mathrm{ha}^{-1}$ rain-fed $v s 9.22 \mathrm{tha}^{-1}$ irrigated) as a result of the reduction of the physiological efficiency of varieties to cope with the harsh weather conditions (Figure 2A; Table 5) (Pala et al., 2007).

In the varieties of autumn and spring cropping system models, the water supplied by irrigation reduced the impact of the weather conditions on the plant development compared to the varieties grown under natural condition. As a result plant development was more consistent and fewer errors were recorded among traits such as DM, moisture at harvest, MFU, plant height and stem $\mathrm{m}^{-2}$ (Figures 2 and 3 ). Therefore, the effect of irrigation versus rain-fed management attenuated the impact of weather conditions on the physiological stress, thus favouring development and relocation of biochemical compounds in the organs of plant (grain, plant high and stem density) (Figures 2A, C and 3; Table 5). However, the significant difference in DM and SY traits between autumn and spring cropping system models under irrigated and rain-fed treatments (3.14 and $8.90 \mathrm{tha}^{-1}$ in DM and 1.13 and 8.47 $\mathrm{t} \mathrm{ha}^{-1}$ in SY, respectively) was related to the efficiency of the photosynthetic process of the varieties used in autumn (C3 plant) and spring (C4 plant) models, which showed a different ability to cope with the harsh weather conditions.

In keeping with Le Gal et al. (2010), the variation of MFU ha ${ }^{-1}$ for silage-silage, silage-seed and seed-seed utilisation was due to the delay of harvests in autumn and spring cropping system models used for seed production (Tables 1 and 6).

Instead of spoiling the silage, the delay in the plant development for seed production spoiled the natural resource for preventing weather impacts in order to sustain respiration physiological process, reduced relocation of stored compounds in the seed organ and, as a consequence, it diminished the MFU ha ${ }^{-1}$ yield when the varieties were used for seed consumption (Groot et al., 2011; Le Gal et al., 2010; Martiniello and Teixteira da Silva, 2011) (Figure 2B; Tables 5 and 6). Thus, the effect of irrigation (mean over cropping system models) on MFU ha-1, in seed-seed utilisation, in comparison to silage-silage and silage-seed, was reduced by $49.0 \%$ and $44.4 \%$ with irrigation and $68.1 \%$ and $61.1 \%$ under rain-fed conditions, respectively (Table 6). However, the weak effect of irrigation on MFU ha ${ }^{-1}$ yield in autumn crop models (27.6\%: 5261 rain-fed vs 7262 irrigated) compared with the spring crop models (42.4\%: 10,691 rain-fed and 18,560 irrigated) was a consequence of the reduced impact of weather conditions (high rain and low temperature) during the period (September-May) on plant development (Figures 1 and 2A, C; Table 5).

According to Tilman et al. (2009) and Martiniello (2011), the different contents of $\mathrm{OC}, \mathrm{N}$ and $\mathrm{P}$ and $\mathrm{K}$ in the soil at the end of the experiment in comparison to those at the beginning was a consequence of the residues left in the rhizosphere during the vegetative cycle of the plant growth process (Table 7).

In line with the results obtained in other experiments by ÁlvaroFuentes et al. (2011), the higher content of $\mathrm{OC}$ and $\mathrm{C} / \mathrm{N}$ in the topsoil in the crop system models based on legumes was due to the effect of the legume varieties on the microbial activity of the topsoil (Table 7).

The means of traits in autumn-spring crop system models under both rain-fed conditions and irrigation treatments based on annual legumes in comparison to those with grasses varieties were higher for $\mathrm{OC}, \mathrm{C} / \mathrm{N}$ and $\mathrm{K}(7.1 \%, 10.5 \%$ and $14.2 \%$ under rain-fed conditions and $16.7 \%, 20.9 \%$ and $8.0 \%$ with irrigation, respectively), while in other traits the variation was lower than $2.0 \%$ (Table 7). In line with Tilman et al. (2009), the lower content of $\mathrm{OC}$ and $\mathrm{C} / \mathrm{N}$ traits in the grass models compared with the legume models of both rain-fed and irrigated treatments was due to the microbial activity which reduced the OC content to provide nutrient cycling for plant development and DM and SY production (Figure 2A; Tables 5 and 7).

The lower $\mathrm{N}$ content in models with irrigation compared with those under rain-fed conditions was a consequence of their higher requirements in terms of DM and plant development (Figures 2A and $3 \mathrm{~A}$ ). Therefore, the lower $\mathrm{N}$ value in the crop system models with irrigation compared with those under rain-fed conditions depends on the requirement of $\mathrm{N}$ to sustain the development of the aerial plant for DM and SY production (Figures 2A and 3A; Table 5).

In agreement with Martiniello (2011) and Álvaro-Fuentes et al. (2011), the reduction of the initial values at end of the OC and N experiment, after three years of continuous rotation under rain-fed and irrigated conditions, was due to the effect of the microbial activity that provides nutrient inputs and sustains plant development for DM and SY production (Figure 2A; Tables 5 and 7).

The autumn crop system models with legume varieties in comparison to those with grasses favoured a sustainable effect on $\mathrm{OC}$ and quality nutrients outputs required for agronomic gross products (ÁlvaroFuentes et al., 2011). In addition, the higher $\mathrm{C} / \mathrm{N}$ value of the cropping system models based on autumn legume varieties under rain-fed and irrigated treatments (10.6 and 9.9, respectively) compared with those based on grass (9.8 and 9.1 under rain-fed and irrigated, respectively) favoured a better biochemical activity of $\mathrm{OC}$ in both irrigation and rainfed treatments (Table 7).

In line with Mohammod (2009), the reduction of the $\mathrm{P}$ and $\mathrm{K}$ content in the models with autumn-sown legume (model I and model IV) and grasses (model II and model III) varieties under rain-fed and irrigated treatments was a consequence of their role in the microbial activity for the mineralisation of residues for cycling nutrient elements (Figure 2A; Tables 6 and 7). Furthermore, the greater K reduction under rain-fed conditions compared with irrigation may be ascribed to the involvement of this element in the mineralisation process to sustain the effect of the stress caused by the impact of the weather conditions on the physiological activity in plant development under natural growing conditions (Table 7). The reduction of the $\mathrm{pH}$ value in grass varieties under rain-fed conditions and in all crop system models with irrigation was attributable to the effect of the microbial activity in the topsoil. According to Pokorny and Stralkova (1999), Krren et al. (2005) and Mohammod (2009), the soil pH at the beginning and at end of experiment was a consequences of the hydrogen ion concentration in the topsoil solution which determines an exchange of the potential reaction and variation of the effect of biological properties (nutrient availability, nitrification and microbial activity of soil) (Table 7). 
The agronomic benefit of annual or perennial forage legume varieties in double cropping system models more with irrigation than under rain-fed growing conditions reduces the agronomic impact of the weather on $\mathrm{OC}$, favours the turnover of biochemical characteristics and extends the edaphic habitat of the fodder crops in the rain-fed UAA of Mediterranean environments.

\section{Conclusions}

Crop system models of autumn legume varieties in comparison to those of grasses increased $0 \mathrm{C}$ by 2.44 with irrigation and $0.99 \mathrm{~g} \mathrm{~kg}^{-1}$ under rain-fed conditions. The irrigated and rain-fed treatments of the crop system models based on autumn legume varieties were less productive in terms of MFU ha ${ }^{-1}$ than in grasses. The use of annual and perennial legume varieties in the crop systems, particularly under irrigated treatment, represents a management practice that can reduce the reduction of $\mathrm{OC}$ in the topsoil of environments with a Mediterranean climate.

The benefits achieved by crop system models based on annual and perennial legume varieties under natural or irrigated growing conditions show that this agronomic approach can recover the OC turnover in the topsoil and sustain forage production in EU environments.

\section{References}

Álvaro-Fuentes J, Easter M, Cantero-Martinez C, Paustinan K, 2011. Modelling soil organic carbon stocks and their changes in the north east of Spain. Eur. J. Soil Sci. 62:685-95.

Bartlett MS, 1937. Some examples of statistical methods of research in agriculture and applied biology. Suppl. J. Royal Stat. Soc. 4:137-83.

Demarquilly C, Andrieu J, Sauvant D, Dulphy JP, 1980. Composition et valour nutritive des aliments. In: R. Jarrige (ed.), Alimentation des ruminants, 2nd ed. INRA, Paris, France, pp 469-518.

Doorenbos J, Kassam AH, 1979. Réponse des Rendemet à l'eau. Bulletin FONI No. 33, Irrigation and drainage. FAO, Rome, Italy.

FAO-ISRIC-ISSS, 1998. World reference base for soil resources. World Soil Resources Report No. 84. FA0, Rome, Italy.

Goering HK, van Soest PJ, 1970. Forage fibre analysis (apparatus, reagents procedures and some applications), Agricultural Handbook 379. USDA/ARS, Washington, DC, USA, pp 1069.

Groot JCJ, Rossing WAH, 2011. Model-aided learning for adaptive management of natural resources: an evolution perspective. Methods Ecol. Evol. 2:643-50.

Kirsten WJ, 1983. Rapid, automatic, high capacity Dumas determination of nitrogen. Microchem. J. 28:529-47.
Kjeldahl A, 1983. Neue Methode zur Bestimmung des Stickstoffs in organischen Kopren. Zeitschr. Ann. Chem. 22:366-82.

Křen J, Neudert L, Lukas V, 2005. How to use information about soil characteristics. pp 391-398 in B. Badalikova (ed.), Soil-agriculture, environment, landscape, Proceeding of $6^{\text {th }}$ ISTRO International Conference (29 June-1 July), Brno, Czech Republic.

Le Gal PY, Merot A, Moulin CH, Navarret M, Wery J, 2010. A modelling frame work to support farmers in designing agricultural production systems. Environ. Model. Software 25:258-68.

Martiniello P, 2011. Cereal-forage rotations effect on biochemical characteristics of topsoil and productivity of the crops in Mediterranean environment. Eur. J. Agron. 35:193-204.

Martiniello P, Gesualdo G, Sabia E, Terzano MG, Pacelli C, Berardo N, 2007. Intensive rain-fed and irrigated forage crop production for Mediterranean Italian buffalo feeding. Ital. J. Animal Sci. 6:1226-9.

Martiniello P, Teixeira da Silva AJ, 2011. Physiological and bioagronomical aspects involved in growth and yield components of cultivated forage species in Mediterranean environments. Eur. J. Plant Sci. Biotechnol. 5:64-98.

Mohammod IS, 2009. Effect of residue qualities on decomposition rates, soil phosphorous dynamics and phosphorous uptake. Adelaide Research and Scholarship Thesis. Unversity of Adelaide, Australia. Available from: http:/hdl.handle.net/2440/49812

Olsen SR, Cole CV, Watanabe FS, Dean LA, 1954. Estimation of available phosphorous in soil by extraction in sodium bicarbonate. US Department of Agriculture, Circular N. 939, pp 1-9.

Pala A, Rayan J, Zhang H, Sing M, Harris HC, 2007. Water-use efficiency of wheat-based rotation systems in a Mediterranean environment. Agric. Water Manage. 16:136-44.

Pokorny E, Stralkova R, 1999. Soil as nutrient transformer in crop rotation. In R. Stralkova R (ed.), International Soil Research Organization, Proceeding of International Conference (29 August2 September), Brno, Czech Republic, pp 186-189.

SAS, 1997. Institute SAS/STAT software: changes and enhancements through release 6.1. SAS Institute Inc., Drive Cary, NC, USA.

Steel RGD, Torrie JH, 1980. Principles and procedures of statistics. A biometrical approach, 2nd ed. McGraw-Hill Book Company, NY, USA.

Tilman D, Cassman, KC, Matson PA, Naylor R. Polasky S, 2009. Agricultural sustainability and intensive production practices. Nature 418:671-7.

UNICHIM, 1985. Determinazione potassio, magnesio, calcio e sodio scambiabile per terreni con $\mathrm{pH}>7.0$ ). Parte I, Manuale 45, Metodo UNICHIM 679, UNICHIM, Milan, Italy, pp 55-60.

Walkley A, Black IA, 1934. An examination of the Degtjareff method for determining soil organic matter and proposed modification of the chromic acid titration method. Soil Sci. 37:29-38. 